\title{
Dental Caries Experience in the Deciduous Dentition of Rural Guatemalan Children Ages 6 Months to 7 Years
}

\author{
PETER F. INFANTE* and GEORGE M. GILLESPIE \\ Center for Human Growth and Development, University of Michigan, Ann Arbor, \\ Michigan 48104, USA and Dental Section, Department of Health Services, \\ Pan American Health Organization, Washington, DC 20037
}

A study of 528 Guatemalan children indicated that caries prevalence in the deciduous dentition was twice as great as but in the permanent dentition was similar to that for US white children. This is a repeated observation for children of some preindustrial societies. Caries experience was significantly greater in boys. Until 4 years of age, caries attack was greater in the anterior segment of the oral cavity; linear enamel hypoplasia was a predisposing factor.

Although data for caries prevalence in preschool-aged children living in industrial societies are available, ${ }^{1-7}$ there is a lack of information from preindustrial societies regarding caries experience during and immediately after emergence of the deciduous dentition. Most observations have been based on the permanent dentition ${ }^{8-10}$ or on the deciduous dentition only after the commencement of deciduous tooth exfoliation.8,11,12 With regard to sex differences in caries attack, data from several studies have shown a slightly greater caries experience in the deciduous dentition in males between the ages of 5 and 13 years $8,13-15$ and a tendency toward a greater caries experience in the permanent dentition in females. ${ }^{8,11,13,16-19}$ Earlier exfoliation of the deciduous dentition accompanied by advanced emergence of the

This paper was prepared as a result of observations made on data collected in conjunction with a more comprehensive study conducted for the Pan American Health Organization and the Institute of Nutrition of Central America and Panama.

Received for publication April 15, 1975.

Accepted for publication April $3,1976$.

- Present address and for reprints: Division of Surveillance, Hazard Evaluations and Field Studies, National Institute for Occupational Safety and Health, Main Post Office Building, Cincinnati, Ohio 45202. permanent dentition in females, however, may have accounted for the differences.

To develop further data on dental caries in infants and preschool-aged children from a preindustrial society, the following study was conducted. Data from a Central American population are presented that show an early initiation of the carious process and a much higher prevalence than do most reports of caries in US preschool children.

\section{Materials and Methods}

In 1973, dental caries examinations were conducted in four rural Guatemalan villages that are participating in a longitudinal study of child growth and development being conducted by the Institute of Nutrition of Central America and Panama. The villages, San Juan, Conacaste, Santo Domingo, and Espiritu Santo, are located in the Department of EI Progreso, which lies about $40 \mathrm{~km}$ northeast of Guatemala City. Three are located at an altitude of 823 meters and the fourth, Espiritu Santo, is located at 275 meters. The climate is hot and dry. The dryest season, March to May, is followed by a rainy season that ends in October to November. Throughout the year, however, there is little variation in temperature. The region is almost wholly agricultural. Racially, the people of all four villages are a mixture of Hispanic and Amerindian stock. In general, they maintain a Latin culture. They constitute a population with generally moderate malnutrition. 20 The four villages are similar in ethnic and sociocultural characteristics. Detailed methods for selection of the four study villages have been published previously.21 Several water samples from each village were obtained at the end of the dry season, which provided an 
TABLE 1

Mean Numbers of Deft and Defs in ladino Children by AGe, Boys, and Girls Combined-Four Rural Guatemalan Villages, 1973

\begin{tabular}{cccccc}
\hline $\begin{array}{c}\text { Age } \\
\text { Group } \\
\text { (yr) }\end{array}$ & $\begin{array}{c}\text { Mean } \\
\text { Age }\end{array}$ & $\mathrm{N}$ & $\begin{array}{c}\text { Mean } \\
\text { deft }\end{array}$ & SD & $\begin{array}{c}\text { Mean } \\
\text { defs }\end{array}$ \\
\hline$<1$ & 0.76 & 28 & 0.00 & 0.00 & 0.00 \\
I & 1.46 & 81 & 0.01 & 0.00 & 0.01 \\
2 & 2.50 & 86 & 1.60 & 2.67 & 2.14 \\
3 & 3.49 & 88 & 3.45 & 4.26 & 4.97 \\
4 & 4.50 & 74 & 5.00 & 4.41 & 7.66 \\
5 & 5.52 & 71 & 5.90 & 4.94 & 9.68 \\
6 & 6.46 & 69 & 6.84 & 4.65 & 11.87 \\
All ages & 3.69 & 497 & 3.43 & & 5.42 \\
\end{tabular}

estimate of maximum fluoride concentration.

Caries examinations for the deciduous dentition were done in 497 children, ages 0.50 to 6.99 years by one examiner (PFI). Thirtyone 12-year-old children also were examined. A mouth mirror, dental explorer, and natural light were used to detect lesions that were then recorded by a trained assistant. No radiographs were made. Children were seated on a wooden chair or held by an adult. Dental caries was expressed in a modification of the deft index. Every effort was made to determine the reason for the relatively few missing teeth at these ages. If a tooth had been extracted, it was categorized as " $e$ " and considered one with caries experience. None of the teeth manifested evidence of restorative dental material and few extractions had been made. Only obvious lesions in which soft dentin could be detected were considered carious lesions. Deep pits and fissures that were sound were not recorded as caries. Extracted posterior teeth were given surface counts of three, whereas extracted anterior teeth were given counts of two. It was thought that these counts were compatible with surface observations for teeth indicated for extraction, though no statistical analyses were made. Posterior and anterior teeth decayed to the gingival line were given surface counts of five and four, respectively. Because of the high prevalence of maxillary anterior linear enamel hypoplasia, which often had become "invaded" by dental caries, it was difficult to determine the progress of decay over the surfaces of the anterior teeth. It would have been difficult to differentiate between two and three surfaces of decay in repeated observations. For this reason, anterior surface counts of one, two, or four were used for anterior teeth still present.

\section{Results}

The total number of decayed, extracted, or filled deciduous teeth (deft) and tooth surfaces (defs) with caries experience were determined for each child. With data for all four villages combined, means and standard deviations for the total numbers of deft and means for defs were computed by one-year age intervals with sex groups both combined and separate. Since caries attack on individual tooth surfaces is not independent, standard deviations for decayed surfaces are not presented. With sex groups combined, the data given in Table 1 show that children at 2 and 5 years of age had an average of 1.6 and 5.9 decayed teeth, respectively. This amounted to a caries experience that was six times greater for 2-year-olds and 1.5 times greater for 5-year-olds as compared with probability-selected US white preschool children examined by the same dentist. ${ }^{22}$ With all age groups combined, caries experience was about twice that reported for US white preschool children.

Mean numbers of decayed teeth and tooth surfaces were then computed for anterior and posterior segments of the arch by one-year age intervals. Posterior surfaces were further subdivided into smooth and pit and fissure surfaces. Since only one child less than 2 years of age had a decayed tooth, these analyses were made only for children between the ages of 2.00 and 6.99 years. These findings are given in Table 2. Comparisons of caries in the anterior and posterior segments 
TABLE 2

Mean Numbers of deft and Mean Smooth and Pit and Fissure

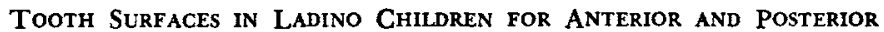
Segments by AGE, Boys and Girls Combined-Rural Guatemala, 1973

\begin{tabular}{|c|c|c|c|c|c|c|c|}
\hline \multirow{3}{*}{$\begin{array}{c}\text { Age } \\
\text { Group } \\
\text { (yr) }\end{array}$} & \multirow[b]{3}{*}{$\mathbf{N}$} & \multirow{2}{*}{\multicolumn{2}{|c|}{ Anterior Segment* }} & \multicolumn{4}{|c|}{ Posterior Segment $†$} \\
\hline & & & & \multirow[b]{2}{*}{$\begin{array}{c}\text { Mean } \\
\text { deft }\end{array}$} & \multirow{2}{*}{$\begin{array}{l}\text { Mean } \\
\text { Smooth } \\
\text { defs }\end{array}$} & \multirow{2}{*}{$\begin{array}{c}\text { Mean } \\
\text { Pit and } \\
\text { Fissure } \\
\text { defs }\end{array}$} & \multirow{2}{*}{$\begin{array}{c}\text { Mean } \\
\text { Smooth } \\
\text { Plus } \\
\text { Pit and } \\
\text { Fissure } \\
\text { Surfaces }\end{array}$} \\
\hline & & $\begin{array}{c}\text { Mean } \\
\text { deft }\end{array}$ & $\begin{array}{c}\text { Mean } \\
\text { defs }\end{array}$ & & & & \\
\hline 2 & 86 & 1.03 & 1.41 & 0.57 & 0.06 & 0.67 & 0.73 \\
\hline 3 & 88 & 1.73 & 2.66 & 1.73 & 0.28 & 2.02 & 2.31 \\
\hline 4 & 74 & 2.24 & 3.59 & 2.76 & 0.61 & 3.46 & 4.07 \\
\hline 5 & 71 & 2.68 & 3.92 & 3.23 & 1.92 & 3.85 & 5.76 \\
\hline 6 & 69 & 2.62 & 3.75 & 4.22 & 3.03 & 5.07 & 8.10 \\
\hline All ages & 388 & 2.01 & 2.98 & 2.38 & 1.08 & 2.87 & 3.96 \\
\hline
\end{tabular}

- Anterior segment includes deciduous incisors and canines.

+ Posterior segment includes deciduous molars.

show that children had a greater number of decayed anterior teeth and tooth surfaces until 4 years of age. With data for all age groups combined, $45.8 \%$ of the total number of carious teeth was observed in the anterior dentition. This is in contrast to $26.3 \%$ in US white children examined during the $\mathrm{Na}$ tional Preschool Nutritional Survey of 19691970.23 This anterior caries attack seems to be associated with the occurrence of linear enamel hypoplasia which often becomes invaded by dental caries in areas of the world where populations experience a high caries prevalence. ${ }^{24-26}$ The hypoplastic defect occurs most frequently in the deciduous maxillary anterior teeth in many of the preindustrial countries. The prevalence in this population was distributed evenly by sex and was estimated to be $31 \%{ }^{27}$
Data were then analyzed separately for each sex as given in Table 3 . Because of the large amount of variability in the number of decayed teeth at each age interval, comparisons of caries experience by sex were based on medians as well as by means. Thus, a median deft trend line was established for boys. Between the ages of 2.50 and 6.99 years, equal numbers of boys were assessed as being above or below the boys' trend line for the number of decayed teeth by age. Girls were then assessed as being above or below the boys' trend line by age. If there was no difference in total deft by sex group, equal numbers of girls should have been above and below the boys' trend line. As given in Table 4, 60.3\% of the girls were below the boys' trend line and $39.7 \%$ were above. These differences were significant,

TABLE 3

MEAN Numbers OF DEFT AND DEFS IN BOYS AND Girls by AgE-Rural Guatemala, 1973

\begin{tabular}{|c|c|c|c|c|c|c|c|c|}
\hline \multirow{2}{*}{$\begin{array}{c}\text { Age } \\
\text { Group } \\
\text { (yr) }\end{array}$} & \multicolumn{4}{|c|}{ Boys } & \multicolumn{4}{|c|}{ Girls } \\
\hline & $N$ & $\begin{array}{c}\text { Mean } \\
\text { Age }\end{array}$ & $\begin{array}{c}\text { Mean } \\
\text { deft }\end{array}$ & $\begin{array}{c}\text { Mean } \\
\text { defs }\end{array}$ & $\mathbf{N}$ & $\begin{array}{c}\text { Mean } \\
\text { Age }\end{array}$ & $\begin{array}{c}\text { Mean } \\
\text { deft }\end{array}$ & $\begin{array}{c}\text { Mean } \\
\text { defs }\end{array}$ \\
\hline 2 & 41 & 2.49 & 2.02 & 2.90 & 45 & 2.51 & 1.22 & 1.44 \\
\hline 3 & 42 & 3.50 & 3.93 & 5.95 & 46 & 3.49 & 3.02 & 4.07 \\
\hline 4 & 40 & 4.52 & 4.66 & 7.05 & 34 & 4.46 & 5.38 & 8.38 \\
\hline 5 & 33 & 5.54 & 7.09 & 12.21 & 38 & 5.50 & 4.87 & 7.48 \\
\hline 6 & 34 & 6.47 & 7.18 & 12.53 & 35 & 6.45 & 6.51 & 11.23 \\
\hline \multicolumn{9}{|l|}{ All } \\
\hline ages & 190 & 4.38 & 4.81 & 7.79 & 198 & 4.34 & 3.99 & 6.13 \\
\hline
\end{tabular}


TABLE 4

Proportion of Girls Above and Below Boys' Trend line for Median Number OF DEFT BY AgE-GuatemalA, 1973

\begin{tabular}{|c|c|c|c|c|c|c|}
\hline \multirow{2}{*}{$\begin{array}{c}\text { Age } \\
\text { Range } \\
\text { (yr) }\end{array}$} & \multicolumn{2}{|c|}{$\begin{array}{l}\text { Girls Above } \\
\text { Boys' } \\
\text { Trend Line }\end{array}$} & \multicolumn{4}{|c|}{$\begin{array}{c}\text { Girls Below } \\
\text { Boys' } \\
\text { Trend Line }\end{array}$} \\
\hline & $N$ & $\%$ & $\mathbf{N}$ & $\%$ & $\chi^{2}$ & $P$ \\
\hline $2.50-6.99$ & 71 & 39.7 & 108 & 60.3 & $7.65^{*}$ & $<0.01$ \\
\hline
\end{tabular}

- Chi-square with $1 \mathrm{df}$.

$P<0.01 \quad\left(\chi^{2}<7.65, d f=1\right)$. The data in Table 3 also show that girls had fewer mean deft at all ages with the exception of 4 -yearolds. Since there were no differences in the percentages of boys and girls who were cariesfree, the sex difference was the result of more extensively decayed teeth in the boys that had caries. A comparison of anterior and posterior decayed teeth by sex further showed that the girls had fewer mean decayed anterior teeth at all ages and fewer decayed posterior teeth at all ages with the exception again of 4-year-olds. (These data are not given in the tables.) The data probably were not consistent for this age group because of the small number of subjects examined.

Dental caries data were then analyzed for each village. To maximize sample size, data were age-standardized to the mean age of children in all of the villages combined. Table 5 gives the mean numbers of decayed teeth in relation to fluoride content in the water samples and to the prevalence of hypoplasia. Santo Domingo, the village with the greatest mean number of decayed teeth, also had the highest prevalence of enamel hypoplasia. The village with the lowest caries prevalence also had the lowest prevalence of hypoplasia. Caries experience in the villages between the extremes followed a similar order. It can also be observed that caries experience followed an inverse relation to the range of fluoride content in the water samples of each village. Because of the low concentration of fluoride in the water of all four villages and the large number of decayed maxillary incisors, the hypoplasia was thought to have had a greater relation to caries experience in the deciduous dentition than did the fluoride concentration in the water.

In addition, thirty-one 12-year-old children also were examined for DMFT and DMFS. With sex groups combined, the mean number of DMFT was 4.94 and DMFS was 7.19. Girls had a greater prevalence than boys.

\section{Discussion}

As a result of the nutritional surveys conducted by the Interdepartmental Committee on Nutrition for National Defense $11,28,29$ as well as some other studies, $12,30-32$ the observation that dental caries experience in several of the preindustrial countries occurs to a more severe degree in the deciduous dentition as compared to the permanent dentition has been well documented. In three Latin American countries, caries prevalence

TABLE 5

Age-Standardized Mfan Total Number of DeFt in Relation to

Prevalence of Linear Hypoplasia and Range of Fluoride IN Water Samples-Four Rural Guatemalan Villages, 1973

\begin{tabular}{lcccc}
\hline \multicolumn{1}{c}{ Village } & $\mathrm{N}$ & $\begin{array}{c}\text { \% with } \\
\text { Hypoplasia }\end{array}$ & $\begin{array}{c}\text { Range of } \\
\text { Fluoride in } \\
\text { Water Samples } \\
\text { (ppm) }\end{array}$ & $\begin{array}{c}\text { Age-Stan- } \\
\text { dardized Mlean } \\
\text { Total Num- } \\
\text { ber deft }\end{array}$ \\
\hline Santo Domingo & 125 & 61.5 & $0.20-0.20$ & 4.42 \\
San Juan & 149 & 24.0 & $0.30-0.33$ & 3.38 \\
Conacaste & 154 & 21.0 & $0.29-0.37$ & 2.91 \\
Espiritu Santo & 69 & 17.7 & $0.34-0.53$ & 2.63 \\
\hline
\end{tabular}


in the permanent dentition has been reported to be about the same as that observed in some US populations where the water supplies had a similar concentration of fluoride $^{33,34}$

The results of this study of Guatemalan children are compatible with the aforementioned findings. Although the sample size for 12-year-old children was small, the caries experience of the permanent dentition in these children seems to be about the same as that reported for some groups of US children who resided in areas with a low fluoride concentration in the water.15,34 The deciduous dentition, however, experienced a prevalence of at least twice the level reported for IIS white preschool children.1-5 In addition, caries in the posterior teeth alone was greater than that reported for total deft in US children. ${ }^{2.5}$ The relatively greater caries attack rates in the anterior teeth seems to be related to the linear hypoplasia; however, reasons for the greater caries attack in the posterior teeth are not apparent. In children from South Vietnam ${ }^{29}$ and Lebanon, ${ }^{11}$ deciduous second molars with extensive decay were seen in proximity to cariesfree permanent first molars time after time. Thus, the disparity in caries attack for the deciduous and permanent dentitions would not seem to be due to the lack of cariogenic bacteria. 29 Russell et al ${ }^{29}$ have suggested that the disparity in the attack rates between the dentitions might be attributed to fluoride in foods received too late in life to affect the deciduous teeth but early enough to inhibit caries in the permanent dentition. This hypothesis was not tested and might merit further investigation.

Since the study population is characterized as being in a state of moderate malnutrition $^{20}$ and the disparity in caries attack between the deciduous and permanent dentitions is usually observed in the preindustrial countries, a theory of nutritional association as an etiologic factor would not seem unreasonable. If some aspect of nutrition were an etiologic factor, however, it is not clear why it should manifest itself to a greater degree in the deciduous dentition unless, perhaps, it were related to some nutritional factor during this period of dental development. A second observation that would be compatible with a theory of nutritional association can possibly be seen by the significantly greater caries attack in boys. Since at birth boys have greater body weight, are developmentally behind, and have less subcutaneous fat than girls, boys would be expected to have greater nutritional requirements and less energy reserves. Thus, factors associated with malnutrition might be expected to reflect themselves to a greater degree in boys than in girls. This may be especially true in areas of moderate malnutrition where refined carbohydrate is part of the normal diet. Data from the Guatemalan nutrition survey 13 similarly show that dental caries in the deciduous dentition was slightly greater in boys, whereas permanent tooth caries experience was greater in females. Because some of the previous findings have been based on deciduous tooth caries during the period of the mixed dentition, earlier deciduous tooth exfoliation in females may have accounted for the differences. Since the sex differences in the present study were observed before the commencement of deciduous tooth exfoliation, the latter is not considered a factor in this study. Because the prevalence of linear enamel hypoplasia was similar in each sex, this defect also was not considered a factor related to the sex differences in caries experience.

Caries prevalence in the deciduous dentition is reported to be low among undernourished children in the preindustrial countries. ${ }^{3 \bar{y}}$ Such findings, however, do not necessarily rule out the possibility that the challenge of a cariogenic diet may not in time result in a greater caries experience in the deciduous dentition in children of relatively poorer nutritional status. Protein malnutrition alone has been shown to be responsible for increased caries susceptibility in rats. ${ }^{36}$ Thus, studies of caries experience in the deciduous dentition in relation to nutritional extremes in other populations would seem appropriate.

Although the possibility exists that the differences in caries experience between vil. lages may have been influenced by natural fluoride content in the water supply, especially in Espiritu Santo where one sample yielded a $0.5-\mathrm{ppm}$ fluoride concentration, the early caries attack in the maxillary incisors suggests that factors associated with the hypoplasia probably had a greater influence on the caries differences. Because there was an inverse relation between the prevalence of hypoplasia and fluoride concentration in the water between the villages, the possibility 
that fluoride may have a preventive effect on the formation of the hypoplasia also was entertained. Since hypoplasia occurs on the portion of the maxillary anterior teeth that is formed during neonatal development, such an event seems unlikely. Fluoride crosses the placental barrier in low concentration, 37,38 and during postnatal development the children are breast-fed and fluoride concentration in breast milk also has been reported to be relatively low. ${ }^{39}$

\section{Conclusions}

A baseline survey of dental caries status in 528 rural Guatemalan children, ages 0.50 to 6.99 and 12 years, indicated that the prevalence of caries in the deciduous dentition of preschool-age children was at least twice as great as the prevalence in US white children; that caries experience in the permanent dentition was the same as that observed in some US communities with low levels of fluoride in the communal water supplies; that caries experience in the deciduous dentition was significantly greater in boys, whereas a tendency for a greater caries attack in the permanent dentition of 12-yearold girls was observed; that the ranking of total caries experience in each village followed the ranking for the prevalence of linear enamel hypoplasia; that until 4 years of age, caries attack was greater in the anterior segment of the oral cavity; and that caries experience in the deciduous molars was greater than that reported for the total deciduous dentition in US children.

The authors acknowledge the collaboration of the Institute of Nutrition of Central America and Panama, and in particular, the staff of the Division of Human Development.

\section{References}

1. Wisan, J.M.; LAvell, M.; and Colwell, F.H.: Dental Survey of Philadelphia Preschool Children by Income, Age and Treatment Status, JADA 55: 1-10, 1957.

2. SAVARA, B.S., and SUHER, T.: Incidence of Dental Caries in Children 1 to 6 Years of Age, J Dent Res 33: 808-823, 1954.

3. INFANTE, P.F., and Russell, A.L.: An Epidemiologic Study of Dental Caries in Preshool Children in the United States by Race and Socioeconomic Level, $J$ Dent Res 53: 393-396, 1974.

4. HenNon, D.K.; STOokeY, G.K.; and MUhler, J.C.: Prevalence and Distribution of Dental Caries in Preschool Children, JADA 79: 1405-1414, 1969.
5. Doering, C.R., and Allen, M.F.: Data on Eruption and Caries of the Deciduous Teeth, Child Dev 13: 113-129, 1942.

6. SAMUelson, G.; GRAkNen, H.; and Lindsтrom, G.: An Epidemiological Study of Child Health and Nutrition in a Northern Swedish County, Odontol Revy 22: 1-32, 1971.

7. Winter, G.B.; RULe, D.C.; Maller, G.P.; JAMES, P.M.C.; and GORDON, P.H.: The Prevalence of Dental Caries in Pre-School Children Aged 1 to 4 Years, Br Dent J 130: 271-277, 1971.

8. Poulsen, S.; Moller, I.J.; Naerum, J;; and Pederson, P.O.: Prevalence of Dental Caries in 2,383 Moroccan School Children Aged 8 and 12, Arch Oral Biol 17: 1165-1175, 1972.

9. Surtin, L.V.; SWEeney, E.A.; and Ascoli, W.: Calcifying Dental Plaque and Reduced Dental Caries in Permanent Molars of Children from Two Guatemalan Villages, J Dent Res 49: 772-775, 1970.

10. RuSSELL, A.L.: International Nutrition Surveys: A Summary of Preliminary Dental Findings, $J$ Dent Res 42: 233-244, 1963.

11. Russell, A.L.: Dental Caries and Nutrition in Lebanon, $J$ Dent Res 45: 957-963, 1966.

12. SWEENEY, E.A., and GuzMan, M.: Oral Conditions in Children from Three Highland Villages in Guatemala, Arch Oral Biol 11: 687-698, 1966.

13. Evaluacion Nutricional de la Poblacion de Centro America Y Panama, Guatemala: Instituto de Nutricion de Centro America $Y$ Panama (INCAP), Guatemala: INCAP, V25, 1969.

I4. Beiger, G.; Perreault, J.G.; and Demirjian, A.: L'etat de sante bucco-dentaire de l'enfant canadien-francais de six a 13 ans, $J$ Can Dent Assoc 38: 378-384, 1972.

15. Summers, C.J.: Dental Needs and Prevalence of Dental Caries in Wayne County Grade School Ghildren, J Mich Dent Assoc 52: 127 $135,1970$.

16. KelLYY, J.E.; van KIRK, L.E.; and Garst, C.C.: Decayed Missing and Filled Teeth in Adults, United States-1960-1962, USPHS, National Center for Health Statistics, series 11, no. 23, Washington, DC: Government Printing Office, February 1967.

17. Bagramian, R.A., and Russell, A.L.: An Epidemiologic Study of Dental Caries in Race and Geographic Area, $J$ Dent Res 50: 1553-1556, 1971 .

18. KUftinec, M.M.: Oral Health in Guatemalan Rural Populations, $J$ Dent Res 50: 559$564,1971$.

19. Sheifam, A.: The Prevalence of Dental Caries in Nigerian Populations, $\mathrm{Br}$ Dent $J$ 129: 144-148, 1967.

20. Habicht, J.P.; SchWedes, J.A.; ARroyave, G.; and KLEIN, R.E.: Biochemical Indices of Nu- 
trition Reflecting Ingestion of a High Protein Supplement in Rural Guatemalan Children, Am J Clin Nutr 26: 1046-1052, 1973.

21. Canosa, C.A.; Salomon, J.B.; and Klein, R.E.: The Intervention Approach: The Guatemala Study, in MOORE, W.M., SILverBERG, M.M., and READ, S.M. (eds): Nutrition, Growth and Development of North American Indian Children, Washington, DC: Department of Health, Education, and Wel. fare Publication No. (NIH) 72-26, 1972, pp 185-189.

22. Infante, P.F., and OWEN, G.M.: Dental Caries and Levels of Treatment for Preschool Children by Geographical Region, Socioeconomic Status, Race and Size of Community, Public Health Dent 35: 19-27, 1975.

23. Infante, P.F.; KraM, K.M.; and OWen, G.M.: Nutritional Status and Dietary Patterns in Relation to Dental Caries Experience in Middle and Lower Socioeconomic Level Preschool Children in the United States, unpublished data.

24. SweEney, E.A.; SAfFir, A.J.; and DeLeon, R.: Linear Hypoplasia of Deciduous Incisor Teeth in Malnourished Children, $A m J$ Clin Nutr 24: 29-31, 1971.

25. Jelliffe, D.B., and JElliffe, E.F.P.: Linear Enamel Hypoplasia of Deciduous Incisor Teeth in Malnourished Children, $\mathrm{Am} \mathrm{J} \mathrm{Clin}$ Nutr 24: 893, 1971.

26. INFAnte, P.F.: Enamel Hypoplasia in Apache Indian Children, Ecology Food Nutr 3: 155156, 1974.

27. Infante, P.F., and Gillespie, G.M.: An Epidemiologic Study of Linear Enamel Hypoplasia of Deciduous Anterior Teeth in Guatemalan Children, Arch Oral Biol 19: 1055 . 1061, 1974.

28. Russel. , A.L.: World Epidemiology and Oral Health, in KRESHover, S.J., and McGLURE, F.J. (eds) : Environmental Variables in Oral Disease, Washington, DC: American
Association for the Advancement of Science Publication No. 81, 1961, pp 21-39.

29. Russell, A.L.; Leatherwood, E.C.; VAN Hien, L.; and van REeN, R.: Dental Caries and Nutrition in South Vietnam, $J$ Dent Res 44: 102-111, 1965.

30. BARRETT, M.J., and WILliamson, J.J.: Oral Health of Australian Aborigines: Survey Methods and Prevalence of Dental Caries, Aust Dent J 17: 37-50, 1972.

31. BaILIT, H.L.: Oral Health of the Nasioi of Bouganville, Aust Dent J 13: 353-359, 1968.

32. BARmes, D.E.: Epidemiology in Papua-New Guinea: Part I. Dental Caries, Aust Dent J 13: 302-312, 1968.

33. Russell, A.L.: Dental Disease in Latin America, $J$ Am Coll Dent 30: 41-52, 1963.

34. Russell, A.L.: Oral Health Study in Children of Suburban Washington, DC, Public Health Rep 71: 626-632, 1956.

35. Enwonwu, C.O.: Socio-Economic Factors in Dental Caries Prevalence and Frequency in Nigerians: An Epidemiological Study, Caries Res 8: 155-171, 1974.

36. Menaker, L., and NAvia, J.M.: Effect of Undernutrition During the Perinatal Period on Caries Development in the Rat: II. Caries Susceptibility in Underfed Rats Supplemented with Protein or Caloric Additions During the Suckling Period, $J$ Dent Res 52: $680-687,1973$.

37. Gardner, D.E.; SMITh, F.A.; Hodge, H.; Overton, D.E.; and Feltman, R.: The Fluoride Content of Placental Tissue as Related to the Fluoride Content of Drinking Water, Science 115: 208-209, 1952.

38. Gedalia, I.; Brzezinski, A.; ZukermaN, H.; and MAYersdorf, A.: Placental Transfer of Fluoride in the Human Fetus at Low and High F-Intake, J Dent Res 43: 669-671, 1964.

39. ZiPKIN, I., and BABEAUX, W.L.: Maternal Transfer of Fluoride, $J$ Oral Ther Pharm 1: 652-665, 1965. 